\title{
EFEK ANTI BAKTERI EKSTRAK KULIT JERUK NIPIS (CITRUS AURANTIFOLIA) TERHADAP SALMONELLA TYPHI SECARA IN VITRO
}

\author{
Donna Pratiwi ${ }^{1}$, Irma Suswati², Mariyam Abdullah ${ }^{3}$
}

\author{
Fakultas Kedokteran Universitas Muhammadiyah Malang, Jalan Bendungan Sutami 188A, Malang, Jawa \\ Timur, 65145, Indonesia, +62341 551149
}

\begin{abstract}
ABSTRAK
Efek Antimikroba Ekstrak Kulit Jeruk Nipis (Citrus aurantifolia) terhadap Salmonella typhi secara In Vitro. Demam tifoid merupakan infeksi akut saluran pencernaan yang disebabkan oleh yaitu Salmonella typhi yang berada pada urutan kedua di antara penyakit usus setelah gastroenteritis. Peningkatan resistensi Salmonella terhadap antimikroba salah satunya kloramfenikol sudah mulai tinggi, sehingga menimbulkan masalah dalam terapi. Kulit jeruk nipis diduga memiliki efek antimikroba karena mengandung minyak atsiri, flavonoid, tanin, saponin, fenol dan alkaloid. Tujuan penelitian adalah untuk membuktikan efek ekstrak kulit jeruk nipis (Citrus aurantifolia) terhadap pertumbuhan bakteri Salmonella typhi. Penelitian ini menggunakan true eksperimental post test only control. Konsentrasi ekstrak kulit jeruk nipis yang digunakan adalah 100\%, $50 \%, 25 \%, 12,5 \%, 6,25 \%, 3,125 \%, 1,56 \%, 0,78 \%, 0,39 \%, 0 \%$. Analisa data menggunakan one way ANOVA, Korelasi, Regresi, Kadar Hambat Minimum, Kadar Bunuh Minimum. Signifikan 0,000 ( $<<0,05)$ pada uji one way ANOVA menunjukkan adanya perbedaan bermakna antar perlakuan pada jumlah koloni. Semakin tinggi ekstrak kulit jeruk nipis, maka semakin sedikit koloni bakteri Salmonella typhi $(\mathrm{r}=-0,586)$. Pemberian konsentrasi ekstrak kulit jeruk nipis berpengaruh terhadap penurunan jumlah koloni bakteri Salmonella typhi (R2=0,34). Hasil penelitian KHM didapatkan pada konsentrasi 12,5\%, dan KBM pada konsentrasi 6,25\%. Ekstrak kulit jeruk nipis memiliki efek antimikroba terhadap Salmonella typhi.
\end{abstract}

\section{ABSTRACT}

The Anti-Microbial Effect of The Extract of Lemon Peel (Citrus aurantifolia) on Salmonella Typhi In Vitro. Typhoid fever is an acute infection of the gastrointestinal tract due to Salmonella typhi which is the occurency of Salmonella typhi is the second among the other bowel disease after gastroenteritis. Increasing antimicrobial resistance of Salmonella chloramphenicol already high was indeed resulting in a problem of therapy. Lemon peel had anti-microbial effect because it contained of volatile oil, flavonoid, tannin, saponnin, fenol and alkaloid. The objective of research was to prove the effect of Lemon peel (Citrus aurantifolia) extract on the growth of Salmonella typhi bacterium. Research method was true experimental post-test only control. Some concentrations of lemon peel extract were used, including $100 \%, 50 \%, 25 \%, 12.5 \%, 6.25 \%, 3.125 \%, 1.56 \%, 0.78 \%, 0.39 \%$, and $0 \%$. Data analysis tool was one-way ANOVA, correlation and regression. Result of one-way ANOVA test at significance level of $0.000(P<0.05)$ indicated that there was a significant difference between treatments on some colonies. The higher lemon peel extract would produce few colonies of Salmonella typhi bacterium $(r=-0.586)$. The concentration of lemon peel extract influenced the reduction of the number of colony of Salmonella typhi bacterium (R2 = 0.34). Minimum Inbibitory Concentration (MIC) cannot be determined, while Minimum Bactericidal Concentration (MBC) was estimated at concentration 6,25\%. Lemon peel extract had anti-microbial effect on Salmonella typhi.

Key words: Lemon peel extract (Citrus aurantifolia), Salmonella typhi, Minimum Inbibitory Concentration, Minimum Bactericidal Concentration

\section{PENDAHULUAN}

Demam tifoid merupakan infeksi akut saluran pencernaan yang disebabkan oleh bakteri gram negatif yaitu Salmonella typhi dan berada pada urutan kedua di antara penyakit usus setelah gastroenteritis (Widodo, 2007). Prevalensi demam tifoid di Kabupaten Malang sebanyak 1,2\% dari 10.966 sampel pada tahun 2007 (Dinkesjatim, 2008). Melihat angka kejadian terserangnya demam tifoid, perlunya pengobatan yang adekuat untuk demam tifoid yang selain untuk penyembuhan total juga untuk meminimalisir komplikasi yang timbul pada penderita demam tifoid seperti perdarahan usus karena perforasi, infeksi kandung empedu (kolesistitis), hepatitis dan gangguan otak seperti esenfalopati (Widodo, 2007).
Pengobatan demam tifoid dilakukan dengan cara pengobatan kausatif. Salah satunya adalah kloramfenikol yang saat ini menjadi pengobatan demam tifoid yang paling sering diresepkan oleh dokter karena ke efektifitasannya yang masih tinggi dan harganya yang relative murah (Musnelina, 2004). Resistensi kuman Salmonella typhi terhadap kloramfenikol sudah mulai tinggi, 25\% dari 47 penderita Demam Tifoid di bagian Mikrobiologi Fakultas Kedokteran Unand pada tahun 2002 di dapat resisten terhadap kloramfenikol. Salah satu tanaman tradisional yang dapat dimanfaatkan sebagai terapi adjuvant sebagai antimikroba terhadap Salmonela typhi adalah jeruk nipis (Citrus aurantifolia). Kulit jeruk nipis mengandung bahan aktif yang diduga dapat memberikan efek antibakteri. Bahan tersebut antara 
lain tannin yang dapat mempengaruhi permeabilitas membrane sitoplasma (Hegerman, 2002), saponin yang dapat menghambat DNA-polymerase, flavonoid yang dapat menghambat sintesa asam nukleat dan meningkatkan permeabilitas membrane (Tim Cushnie, 2005), fenolat juga bisa meningkatkan permeabilitas membrane (Cetin, 2011) dan alkaloid yang dapat merusak membrane mikroba dan dapat mengganggu sintesa asam nukleat pada bakteri (Robinson,1991). Minyak atsiri dapat meningkatkan fluiditas dan permeabilitas membrane sehingga merusak membrane yang mengikat protein transport, menghambat respirasi dan merubah proses transpor ion dalam bakteri (Sikkema et al. 1994; Trombetta et al. 2005). Sehingga di duga kulit jeruk nipis yang mengandung fenol dapat menjadi antibakteri Salmonella typhi.

Penelitian ini bertujuan untuk mengetahui aktivitas antibakteri ekstrak kulit jeruk nipis terhadap Salmonella typhi. Selain itu juga untuk menentukan besarnya Kadar Hambat Minimum (KHM) dan Kadar bunuh Minimum (KBM ) ekstrak kulit jeruk nipis ekstrak kulit jeruk nipis (Citrus aurantifolia) terhadap bakteri Salmonella typhi. Manfaat yang diharapkan dari penelitian ini adalah memberikan bukti ilmiah penggunaan kulit jeruk nipis sebagai antimikroba dan dapat digunakan sebagai dasar penelitian lebih lanjut secara in vivo untuk mengetahui dosis yang paling tepat untuk penggunaan sistemik Penelitian ini juga diharapkan bisa menjadi salah satu solusi atas tingginya biaya pengobatan penyakit infeksi saat ini dalam usaha mendapatkan terapi adjuvant yang murah, efektif, aman dan mudah didapat.

\section{METODE}

Penelitian ini merupakan penelitian Eksperimental dengan desain true experimental post test only control group design. Penelitian ini dilaksanakan di laboratorium Mikrobiologi Universitas Muhammadiyah Malang pada bulan Desember 2012 sampai Januari 2013.

Populasi dalam penelitian ini adalah bakteri Salmonella typhi biakan feses murni yang diperoleh dari Laboratorium Mikrobiologi Fakultas Kedokteran Universitas Muhammadiyah Malang. Sedangkan sampel dalam penelitian ini adalah bakteri Salmonella typhi biakan murni dengan menggunakan Simple Random Sampling. Penelitian menggunakan 8 kelompok perilaku ekstrak kulit jeruk nipis dan 2 kelompok kontrol. Sehingga ada 10 kelompok. Estimasi besarnya replikasi yang digunakan pada penelitian ini adalah tiga kali pengulangan untuk sampel (Supranto, 2007).

Alat dan bahan yang digunakan pada penelitian ini dibagi menjadi beberapa bagian, yaitu : alat dan bahan untuk identifikasi bakteri, alat dan bahan ekstraksi kulit jeruk nipis, serta alat dan bahan uji antimikroba.

Data yang diperoleh yaitu data konsentrasi ekstrak kulit jeruk nipis dan jumlah koloni bakteri. Analisis yang digunakan adalah uji ANOVA one way, uji korelasi Pearson dan uji regresi linier. Uji one way ANOVA digunakan pada jenis data lebih dari dua kelompok tidak berpasangan dengan jenis asosiasi komparatif (perbandingan) dan skala pengukuran variabel numerik (Dahlan, 2009). Uji ini juga untuk menganalisis perbedaan bermakna terhadap pengaruh perlakuan beberapa konsentrasi ekstrak kulit jeruk nipis dalam menghambat pertumbuhan Salmonella typhi. Uji korelasi Person, uji ini digunakan untuk menilai arah hubungan linier antara peningkatan konsentrasi ekstrak kulit jeruk nipis dan jumlah koloni Salmonella typhi yang dapat tumbuh pada media biakan (Tjokronegoro A, 2001). Uji regresi linier, uji ini untuk mencari seberapa kuat hubungan yang ada antara peningkatan konsentrasi ekstrak kulit jeruk nipis dan penurunn jumlah koloni bakteri Salmonella typhi.

\section{HASIL DAN PEMBAHASAN \\ Kadar Hambatan Minimum (KHM) Ekstrak Kulit Jeruk Nipis}

Hasil pengamatan pada uji dilusi tabung setelah diinkubasi selama 18-24 jam pada suhu 37oC, yang telah dilakukan 3 kali didapatkan berada pada konsentrasi 12,5. Hal ini dapat dilihat dari penilaian tingkat kejernihan tabung yaitu dengan tampaknya secara jelas garis hitam dibelakang tabung.

\section{Kadar Bunuh Minimum (KBM) Ekstrak Kulit Jeruk Nipis}

Setelah dilakukan uji dilusi tabung kemudian biakan dari semua tabung digoreskan ke media SS, diinkubasi dan diamati keesokan harinya untuk melihat ada tidaknya koloni Salmonella typhi yang tumbuh. Konsentrasi terendah ekstrak kulit jeruk nipis pada biakan padat yang ditunjukkan dengan tidak adanya pertumbuhan koloni Salmonella typhi adalah KBM dari ekstrak kulit jeruk nipis terhadap bakteri Salmonella typhi.

Tabel 1 Rata-rata jumlah koloni Salmonella typhi per cawan dalam beberapa konsentrasi ekstrak kulit jeruk nipis

\begin{tabular}{cc}
$\begin{array}{c}\text { Kadar ekstrak kulit jeruk } \\
\text { nipis }\end{array}$ & $\begin{array}{c}\text { S koloni bakteri } \\
\text { Salmonella typhi per cawan }\end{array}$ \\
\hline $100 \%$ & 0 \\
$50 \%$ & 0 \\
$25 \%$ & 0 \\
$12.5 \%$ & 0 \\
$6,25 \%$ & 0 \\
$3,125 \%$ & 660 \\
$1,56 \%$ & 917,33 \\
$0,78 \%$ & 1042,67 \\
$0,39 \%$ & 1217,33 \\
$0 \%$ & 1378,67 \\
\hline
\end{tabular}

Sumber : data primer (2013)

Dari tabel 1 memperlihatkan bahwa pada setiap peningkatan konsentrasi ekstrak kulit jeruk nipis terjadi penurunan jumlah koloni bakteri Salmonella typhi pada tiap pengulangan. Dengan penurunan jumlah koloni bakteri Salmonella typhi yang cukup tajam setelah diberikan konsentrasi ekstrak kulit jeruk nipis 6,25\%. KBM didapatkan jika pada SS tidak menunjukkan pertumbuhan koloni bakteri atau ada penurunan $99,9 \%$ dari inokulum asal pada sub-biakan, karena berdasarkan rata-rata jumlah koloni yang tumbuh pada original inoculum adalah sebesar 1378,67, maka konsentrasi yang ditetapkan sebagai KBM adalah 6,25\% karena pada konsentrasi ini jumlah bakteri pada KBM dapat 
ditetapkan sebesar $<1$ koloni (0,1\% dari total koloni pada original inoculum) dimana pada konsentrasi 6,25\% jumlah bakteri sebesar 0 .

Berdasarkan hasil penelitian, dapat ditentukan nilai KBM (Kadar Bunuh Minimum) dapat ditentukan hasilnya yaitu pada konsentrasi 6,25\% yang ditandai dengan adanya penurunan pertumbuhan koloni bakteri sebesar $99.9 \%$ dari jumlah koloni Salmonella typhi pada original inoculums. Hal ini sejalan dengan dengan penelitian terdahulu yang dilakukan oleh Taiwo 2007, bahwa ekstrak kulit jeruk nipis dapat mempengaruhi pertumbuhan pada bakteri Salmonella sp., Staphylococcus sp, E. coli, Klebsiella sp, Proteus sp. dan Pseudomonas sp.

\section{Analisis Data}

Dari hasil penelitian yang telah dilakukan, kemudian data dianalisis dengan analisis ragam satu arah dengan syarat data harus terdistribusi dengan normal dan ragam yang homogen. Berdasarkan hasil tes normalitas dengan menggunakan uji Kolmogorov-Smirnov dan kesamaan (homogenitas) ragam dengan menggunakan uji Levene diperoleh bahwa data jumlah koloni bakteri Salmonella typhi per cawan yang telah diuji mempunyai kenormalan data dengan hasil 0.292 dan kesamaan ragam data dengan nilai 0.892 , sehingga dapat dilakukan pengujian lebih lanjut yaitu ANOVA.

Berdasarkan hasil analisis ragam pada tabel 2 didapatkan nilai signifikan (p) sebesar 0.000 yang lebih kecil dari 0.05 , dengan demikian maka dapat disimpulkan bahwa terdapat perbedaan yang bermakna pada perlakuan dari kedelapan konsentrasi ekstrak kulit jeruk nipis terhadap jumlah koloni Salmonella typhi per cawan.

\begin{tabular}{cccccc}
\hline Sumber Keragaman & $\begin{array}{c}\text { Jumlah } \\
\text { kuadrat }\end{array}$ & $\begin{array}{c}\text { Derajat } \\
\text { bebas }\end{array}$ & Kuadrat tengah & Fhitung & Nilai p \\
\hline Antar Kelompok & 9078633 & 9 & 1.008 .736 .948 & 161.634 & 0.000 \\
Dalam kelompok & 142422.7 & 20 & 7.122 .133 & & \\
\hline Total & 9221075 & 29 & & & \\
\hline Sumber : data primer (2013) & & & &
\end{tabular}

Untuk mengetahui konsentrasi ekstrak kulit jeruk nipis mana saja yang berbeda secara signifikan (bermakna) dan tidak berbeda signifikan pengaruhnya terhadap jumlah koloni, maka dilakukan uji lanjut Tukey. Uji Tukey digunakan untuk membandingkan seluruh pasangan rata-rata perlakuan setelah uji Analisis Ragam di lakukan.

Pada perbandingan jumlah koloni bakteri Salmonella typhi per cawan antara kelompok kontrol $(0 \%)$ dengan kedelapan kelompok konsentrasi ekstrak kulit jeruk nipis yang lain menunjukkan perbedaan yang signifikan (bermakna). Namun pada konsentrasi ekstrak kulit jeruk nipis $100 \%, 50 \%, 25 \%, 12,5 \%$ dan $6,25 \%$ tidak menunjukkan adanya perbedaan pengaruh yang signifikan, begitu pula pada konsentrasi $1,56 \%$ dan $0,78 \%, 0,78 \%$ dan $0,39 \%, 0,39 \%$ dan $0 \%$ juga tidak menunjukkan adanya perbedaan pengaruh jumlah koloni Salmonella typhi yang signifikan. Konsentrasi ekstrak kulit jeruk nipis 3,25\% mempunyai perbedaan pengaruh dengan konsentrasi $1,56 \%$, $0,78 \%, 0,39 \%$ terhadap jumlah koloni bakteri. Konsentrasi $1,56 \%$ dan $0,78 \%$, mempunyai perbedaan pengaruh dengan konsentrasi $50 \%, 25 \%, 3,125 \%, 0,39 \%$. Konsentrasi 0,78\% dan $0,39 \%$, mempunyai perbedaan pengaruh dengan konsentrasi $50 \%, 25 \%, 12,5 \%, 6,25 \%, 1,56 \%$. Konsentrasi $0,39 \%$ dan $0 \%$ mempunyai perbedaan pengaruh dengan konsentrasi 50\%, 25\%, 12,5\%, 6,25\%, 3,125\%, 0,78\%.

Pengaruh perlakuan ke delapan konsentrasi ekstrak kulit jeruk nipis terhadap jumlah koloni bakteri Salmonella typhi per cawan, dapat ditunjukkan pada gambar 1 di bawah ini :

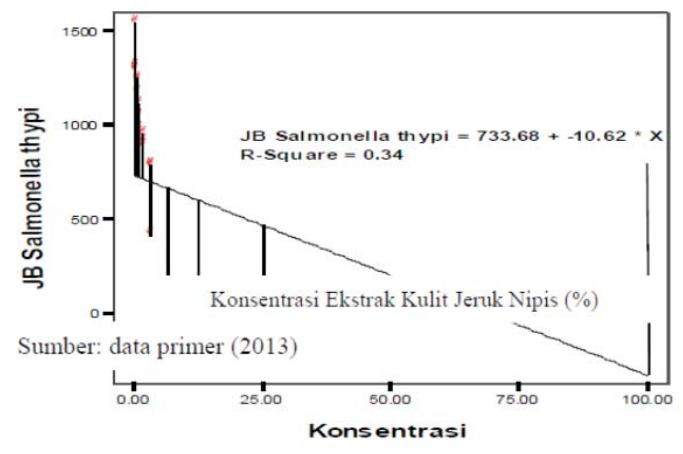

Gambar 1. Grafik Linier Regresi

Dari grafik linier regresi tersebut dapat dibentuk urutan dari perlakuan konsentrasi ekstrak kulit jeruk nipis terhadap jumlah koloni Salmonella typhi yang paling banyak sampai sedikit hingga nol (tidak ada pertumbuhan koloni) sebagai berikut : Kontrol kuman ( $0 \%$, konsentrasi 0,39\%, 0,78\%, $1,56 \%, 3,125 \%$ dan 6,25\%. Jadi dapat disimpulkan bahwa penggunaan ekstrak kulit jeuk nipis dalam konsentrasi 6,25\% telah mampu membunuh Salmonella typhi meskipun masih diperlukan penelitian lebih lanjut.

Untuk mengetahui besarnya hubungan dan pengaruh dari perlakuan kedelapan macam konsentrasi ekstrak kulit jeruk nipis terhadap jumlah koloni bakteri Salmonella typhi per cawan, maka dilakukan uji korelasi dan regresi linier sederhana.

Diperoleh nilai korelasi bagi konsentrasi ekstrak kulit jeruk nipis terhadap jumlah koloni Salmonella typhi per cawan sebesar - 0.586 . Hal ini berarti peningkatan konsentrasi ekstrak kulit jeruk nipis akan relatif menurunkan jumlah koloni bakteri Salmonella typhi per cawan secara signifikan dan tingkat hubungan antara ekstrak kulit jeruk dan Salmonella typhi adalah sedang (Sofiudin,2005). 
Untuk mengetahui seberapa besar pengaruh konsentrasi ekstrak kulit jeruk nipis terhadap jumlah koloni Salmonella typhi per cawan, digunakan analisis bentuk regresi karena uji korelasi hanya mengetahui hubungan. Analisis regresi ini digunakan untuk mengetahui besarnya pengaruh antara variabel bebas yaitu pemberian berbagai macam konsentrasi ekstrak kulit jeruk nipis terhadap jumlah koloni Salmonella typhi per cawan.

Berdasarkan Tabel 5.5 menunjukkan nilai koefisien determinasi ( $\mathrm{R}$ square $=\mathrm{R} 2$ ) untuk jumlah koloni bakteri Salmonella typhi per cawan sebesar 0.34. Nilai koefisien determinasi tersebut menunjukkan besarnya pengaruh dari kedelapan macam konsentrasi ekstrak kulit jeruk nipis terhadap jumlah koloni bakteri Salmonella typhi per cawan yaitu sebesar 34\% (0.34x100\%), sedangkan sisanya ditentukan oleh faktor lain yang tidak diteliti.

Berdasarkan hal tersebut maka terbukti adanya linieritas dari kedelapan macam konsentrasi ekstrak kulit jeruk nipis terhadap jumlah koloni bakteri Salmonella typhi per cawan. Hal ini diperkuat dari hasil dari koefisien korelasi untuk kedelapan macam konsentrasi ekstrak kulit jeruk nipis terhadap jumlah bakteri Salmonella typhi per cawan yaitu sebesar -0.586, dimana menunjukkan arah korelasi yang negatif (koefisien korelasi bernilai negatif). Artinya semakin tinggi konsentrasi ekstrak kulit jeruk nipis, maka akan semakin menurunkan jumlah koloni bakteri Salmonella typhi per cawan.

\begin{tabular}{lccccc}
\hline \multicolumn{2}{l}{ Jumlah koloni per cawan } & & & & \\
\hline \multicolumn{1}{c}{ Variabel } & $\begin{array}{c}\text { Koefisien } \\
\text { regresi }\end{array}$ & \multirow{2}{*}{ Beta } & T hitung & Nilai & Keterangan \\
\hline Konstanta & 733.677 & & 7.236 & 0.000 & Signifikan \\
Konsentrasi & -10.625 & -0.586 & -3.826 & 0.001 & Signifikan \\
\hline R square (R2) $=0.34$ & & & & & \\
\hline Sumber : data primer (2013) & & & &
\end{tabular}

Bahan-bahan aktif yang terdapat dalam kulit jeruk nipis yaitu zat minyak atsiri, fenolat, alkaloid, flavonoid, saponin dan tannin merupakan bahan-bahan aktif yang memiliki daya antimikroba pada kulit jeruk nipis (Cetin, 2011), (Robinson,1991), (Tim Cushnie, 2005), (Hegerman, 2002), Keenam bahan tersebut dapat mempengaruhi struktur Salmonella typhi. Kandungan monoterpen pada minyak atsiri dapat menghambat pertumbuhan bakteri. Umumnya monoterpen bersifat lipofilik. Monoterpen telah dibuktikan lebih cenderung berdifusi ke fasa struktur membran bakteri dibandingkan fasa air. Terakumulasinya molekul monoterpen ke fasa membran akan membuat membran mengalami pengembangan (Swelling), meningkatkan permeabilitas membran sehingga merusak membran yang mengikat protein sel bakteri, bakteri akan membentuk enzim dari dalam sel yang disebut permease yang merupakan suatu protein sel ( Sikkema et al. 1994; Trombetta et al. 2005).

Tannin dinamakan juga asam tanat dan asam glutanat. Biasanya tidak berwarna tetapi ada juga yang berwarna coklat. Istilah tannin yang dipakai ahli pangan ada dua yaitu ; tannin terkondensasi (condensed tannin) dan tannin terhidrolisasi (bidrolized tannin). Tanin merupakan salah satu senyawa kimia yang termasuk dalam golongan polifenol yang diduga dapat mengikat salah satu protein membran yang dimiliki oleh bakteri dan apabila hal ini terjadi maka dapat merusak ketersediaan reseptor pada permukaan sel bakteri sehingga menganggu proses metabolisme sel tersebut. Tanin telah dibuktikan dapat membentuk kompleks senyawa yang irreversibel dengan prolin, yaitu suatu protein lengkap, yang mana ikatan ini mempunyai efek penghambatan sintesis protein untuk pembentukan dinding sel (Hegerman, 2002).

Saponin merupakan jenis dari phytonutrien yang banyak ditemukan pada kacang-kacangan, ginseng dan lidah buaya. Detergen alami dapat menurunkan tekanan antar molekul karena mempunyai gugus hidrokarbon yang larut lemak (berada pada membran sel) dan gugus larut air (berada pada lingkungan air). Saponin terdiri dari gugus gula yang berikatan dengan aglikon/ sapogenin yang merupakan yang hasil hidrolisis dari glikosida yang dapat menghambat DNA-polymerase sehingga sintesa asam nukleat terganggu yang akhirnya dapat menganggu inti sel dari bakteri. Mekanisme Saponin sebagai anti mikroba adalah terjadinya ikatan antara saponin dengan sterol (protein bakteri) pada permukaan membran sel bakteri yang dapat meningkatkan permeabilitas membran sel bakteri sehingga dapat mengubah struktur dan fungsi membran, menyebabkan denaturasi protein, sehingga membran sel akan rusak dan lisis. (Suparjo, 2008).

Mekanisme aksi penghambatan senyawa fenolat pada mikro organisme di karenakan oleh gangguan pada integritas membran sel dan sintesis komponen struktural bakteri. Aktivitas antimikroba dari senyawa fenolik terkait dengan inaktivasi enzim seluler, yang tergantung pada tingkat penetrasi zat ke dalam sel atau disebabkan oleh zat perubahan permeabilitas membran ke dalam sel atau disebabkan oleh perubahan permeabilitas membran. Permeabilitas membran yang meningkat merupakan faktor utama dalam mekanisme antimikroba, dimana senyawa dapat mengganggu membran dan menyebabkan hilangnya integritas sel dan kematian sel akhirnya (Cetin, 2011).

Alkaloid sebagai antibakteri diprediksi melalui penghambatan sintesis dinding sel yang akan menyebabkan lisis pada sel sehingga sel akan mati. Alkaloid dari tanaman kebanyakan merupakan senyawa amina tersier dan yang lainnya terdiri dari nitrogen primer, sekunder, dan quartener (Poither,2000). Semua alkaloid mengandung paling sedikit satu atom nitrogen yang biasanya bersifat basa dan sebagian besar atom nitrogen ini merupakan cincin aromatis (Mustarichie, 2011). Mekanisme kerja alkaloid sebagai antibakteri adalah dengan cara mengganggu komponen penyusun peptidoglikan pada sel bakteri, sehingga lapisan dinding sel tidak terbentuk secara utuh dan menyebabkan kematian sel tersebut (Robinson,1991). 
Hal lain yang mempengaruhi kepekaan Salmonella typhi terhadap ekstrak kulit jeruk nipis jika dilihat dari segi daya tahan bakteri, kuman ini mati pada suhu 56oC dan pada kondisi kering. Dalam air bisa tahan selama 4 minggu (Jawetz, 2008). Salmonella typhi adalah bakteri yang berdasarkan kebutuhan oksigenasi bersifat fakultatif anaerob, membutuhkan suhu optimal 37oC untuk pertumbuhannya (Darmawati, 2009). Hal ini sudah sesuai dengan suhu inkubator yang digunakan pada penelitian yaitu sebesar $37 \mathrm{oC}$.

Dari hasil penelitian yang telah dilakukan, maka ekstrak kulit jeruk nipis dapat digunakan sebagai antimikroba untuk terapi pasien dengan infeksi Salmonella typhi. Tentu saja diperlukan berbagai pengujian terlebi dahulu sebelum diaplikasikan sebagai antimikroba kepada masyarakat antara lain adalah uji preklinik, serta uji klinik.

\section{KESIMPULAN}

Berdasarkan hasil dan pembahasan dalam penelitian ini dapat ditarik kesimpulan sebagai berikut ekstrak kulit jeruk nipis (Citrus aurantifolia) memiliki daya antimikroba terhadap bakteri Salmonella typhi dengan nilai signifikan (p) sebesar 0.000 dan $\mathrm{r} 2$ sebesar 0,34 . Semakin tinggi konsentrasi ekstrak kulit jeruk nipis, semakin menekan pertumbuhan bakteri Salmonella typhi, nilai KHM (Kadar Hambat Minimum) ekstrak kulit jeruk nipis berada pada konsentrasi 12,5\% dan nilan KBM (Kadar Bunuh Minimum) ekstrak kulit jeruk nipis pada konsentrasi 6,25\%

\section{DAFTAR PUSTAKA}

Agusta, Andria.2000. Minyak Atsiri Tumbuhan Tropika Indonesia. ITB, Bandung. Hal: 53

Ahmad Nasiq, 2012, Manfaat Jeruk Nipis untuk Kesehatan dan Kecantikan. http://ahmadnaziq.blogspot.com/ 2012/06/manfaat-jeruk-nipis.html

Arsyi Ismi, 2008, Uji Aktivitas Antibakteri Fraksi Etil Asetat Ekstrak Etanolik Daun Arbenan (Duschesnea indica(Andr.) Focke) terhadap Staphylococcus aureus dan Pseudomonas aeruginosa Multiresisten Antibiotik Beserta Profil Kromatologi Lapis Tipisya.

Balbi H J, 2004, Chloramphenicol American Academy of Pediatrics, Pediatrics in Review 25, pp:284-288.

Cetin Hayriye, 2011, Evaluation of Antimicrobial Phenolic Compounds Agains FoodBorne Phatogen,. University of Kentucky.

Cushnie Tim, dkk, 2005, Antimicrobial Activity of Flavonoids. School of pharmacy, The Robert Gordon University. UK

Darmawati S, 2009, Keanekargaman Genetik Salmonella typhi, diakses 22 September2012 http:// www.jurnal.animus.ac.id/idex.php/Analisis/article/ download/225/27

Darmowandodo Widodo, Udjiani Pawitro Edi, Monique Noorvitry, 2005, Demam Tifoid, Ilmu Penyakit Anak Diagnosa \& Penatalaksaan. EGC. Jakarta,pp: 1 - 49.

Dian Christina L., 2011. Pola Resistensi Antibiotik Kloramfenikol, Thiamfenikol dan Siproflosasin terhadap Bakteri Salmonella typhi pada beberapa pasien di rumah Sakit Braat Minulya Tahun 2010 secara Difus.
Universitas Setia Budi Surakarta (http://setiabudi.ac.id/ digilib/index.php? act=view\&id=9157)

Departemen Kesehatan Jawa Timur, 2008, Laporan Kesehatan Tahun 2008. Surabaya.

Dzen, Soekoer M.,et al. 2003. Bakteriologi Medik, Bayumedia Publising, Malang, Hal: 122-187.

Hegerman, Ann E, 2002, Tanin Chemistry (online), diakses pada tanggal 23 Mei 2012. (http:/www. biochemistry.com/ chemistry/departement/textbook/php)

Irianto, K. 2006. Mikrobiologi Menguak Dunia Mikroorganisme. Cetakan Pertama. Bandung :Yrama Widya Kadriya,. 2004.Chemical Composition Of The Essential Oil Of Tagetes Minuta Growing in Saudi Arabia,Saudi Pharmaceutial Journal,Vol 12

Julius, E.S. 1990. Mikrobiologi Dasar. Jakarta : Binarupa Aksara

Jawetz E, Melnick J.L, \&Adelberg E.A, 2008. Mikrobiologi Kedokteran Edisi 23, Jakarta:EGC.

Kaiser, Gary, 2001, Structure of a Gram-Negative Cel Wall, Diakses tangal 29 Oktober 2011, (http:// faculty.ccbcmd.edu/coursesbio141/labmanua/lab12/ disease/ecoli/u1 fig10b)

Katzung, B.G., 1998, Basic and Clinical Pharmacology, 7th ed. Musnelina lili, 2004, Analisis Efektivitas Biaya Pengobatan Demam Tifoid Anak Menggunakan Kloramfenikol dan Seftriakson di Rumah Sakit Fatmawati Jakarta ,Tahun 2001 - 2002.

Mustarichie et al, 2011. "Activity of Leaf Extracts of Coix lachryma Linn. and Asparagus Cochinchinensis Linn. as Breast Anticancer Drugs". Medical and Health Science Journal 9 (5): 47-57.

Okwu D.E, et al, 2007, Phytochemical Composition and In Vitro Antifungal Activity Screening of Extract from Citrus Plants agains Fusarium Oxysporum of Okera Plant (Hibiscus esculentus).

Purwanto. Demam tipoid. 2009 (www.geocitic.com.)

Robinson, T., 1991, Kandungan Organik Tumbuhan Tingkat Tinggi, ITB, Bandung : 132-6.

Sarwono B, Khasiat dan Manfaat Jeruk Nipis, Jakarta: Agromedia Pustaka 2006: 23-25

Sikkema J, Bont JAM de, poolman B. 1994. Interaction of cyclic hydrocarbons with biological membranes. Journal of Biologycal Chem 269(11), page : 8022-8028

Simanjuntak $\mathrm{CH}$. Masalah demam tifoid di Indonesia. Cermin dunia kedokteran, 1990;60: 31-4.

Slamet Sudarmadji. 1997. Prosedur Analisa Bahan Makanan dan Pertanian. Cetakan keempat. Penerbit : Liberty Yogyakarta.

Sjahruachman, A. Pengembangan Teknik Deteksi IgM-anti Flagel Salmonella secara Imunoasay untuk Diagnosis Cepat Demam Enterik. 2009

Sjoekoer M,dkk, Efek Antimikroba Ekstrak Rimpang Temulawak ( Curcuma xanthorissa) terhadap Bakteri Salmonella typhi. Universitas Brawijaya

Sopiyudin Dahlan, 2001. Statistik Untuk Kedokteran dan Masyarakat. Fakultas Kedokteran Universitas Indonesia

S.S Taiwo et all, 2007, In vitro Antimicrobial A ctivity of Crude Extracts of Citrus aurantifolia Linn and Tithonia diversifolia Poaceae on Clinical Bacterial Isolates, Department of medical Microbiology and Parasitology, College Health Science, Ladoke Akintola Univ. of Technology 
Suharman, dkk, 2010, Resitensi Salmonella typhi terhadap Beberapa Jenis Antimikroba di Padang, Universitas Andalas.

Sumarsih S, 2003, Mikrobiologi Dasar, diakses 30 September 2012, sumarsih07. files.wordpress.com/2007/12/bukuajar-mikrobiologi.pdf

Suparjo, 2008, Saponin dalam Jurnal Fakultas Peternakan Universitas Jambi, diakses 19 Mei 2009, http:// jajo66.files.wordpress.com/2008/06/saponin.pdf

Tombetta D et al. 2005. Mechanism of antibacterial action of three monoterpens. Antimicrobial Agent and Chemotheraphy 49(6); 2427-2478.

Todar .K, PhD. 2008. Salmonella and Salmonellosis.(http:/ /www. text book ofbacteriology.net/salmonella.html) (30desember 2009, 20.30)

Volker Brinkmann, 2004, Evolution of typhoid bacteria http:/ /phys.org/news83593133.html

Widodo Djoko, 2007, Demam Tifoid, Imu Penyakit Dalam, Edisi IV,F akultas Kedokteran Universitas Indonesia. Jakarta.pp: 1752-175. 